\section{Medical research}

\section{Backs to the wall in Britain}

THF: British Medical Rescarch Council (MRC) faces a deficit of $£ 13.2$ million by the end of the decade even if it does no more than maintain the existing rate of awards and renew long-term grants at an appropriate level. But there is also a pressing need to spend more on research into AIDS (acquired immune deficiency syndrome) and to offer more competitive salaries to keep the best scientists, says Sir James Gowans, secretary of MRC.

Introducing the council's annual report in the year before he retires, Gowans described AIDS as a "national emergency" that deserves special earmarked research funds. Discussions with government departments seem likely to produce the $£ 0.5$ million needed immediately for one major and two minor AIDS projects, but several million pounds will be needed over the next few years. (A bare $£ 2$ million was spent on AIDS research by MRC and the Department of Health and Social Services in the past year compared with the $\$ 40$ million predicted for 1987 in the United States.) Priority must be given to monitoring the spread of the virus that causes AIDS and the effect of the campaign to reduce the spread, said Dr D. A. J. Tyrrell, chairman of the MRC working party on AIDS. But neither he nor Gowans would be drawn on how to overcome the problems that are holding up monitoring (see Nature 324, 396; 1986).

On salaries, Gowans expressed frustration that MRC's grant-in-aid, worth $£ 129$ million last year, assumes an increase of only 3 per cent this year and 2.5 per cent next year when pay awards are running at $5-6$ per cent. The level of awards for its staff is not controlled by MRC as it is tied to increases for their university, clinical and civil service equivalents. That, and the decreasing budget, also constrains the ability of MRC to offer salaries that compete with offers from industry and overseas. At the top level, however, the council is free to offer more competitive salaries as long as the mean is maintained at the average for professors in universities, which have the same flexibility.

Unless the MRC budget is increased, said Gowans, it will be extremely difficult for the council to grasp new opportunities in research. The problem is already very serious; 90 project grants were approved but not funded in the past financial year. Royalty income from discoveries made by MRC scientists is expected to increase in coming years, particularly through the activities of the new Centre for Collaborative Research. But last year it was only $£ 0.1$ million and a limit of $£ 2.5$ million has been imposed.

Peter Newmark

Japanese volcanoes \title{
Forecasters wise after the event
}

\section{Tokyo}

JAPAN's Volcanic Prediction Liaison Council seems to have been rewarded for its failure to forecast the behaviour of Mount Mihara on Oshima, the volcanic island south of Tokyo evacuated during a major eruption last month. The council has won substantial new facilities on the island that will make Mihara one of the best-monitored volcanoes in the world.

The council, advisor to the Meteorological Agency, has come under fire for its pronouncements about Mount Mihara. At the end of October, following the outbreak of volcanic tremors, the council declared that any eruption would be "several months or years" away. Even when the

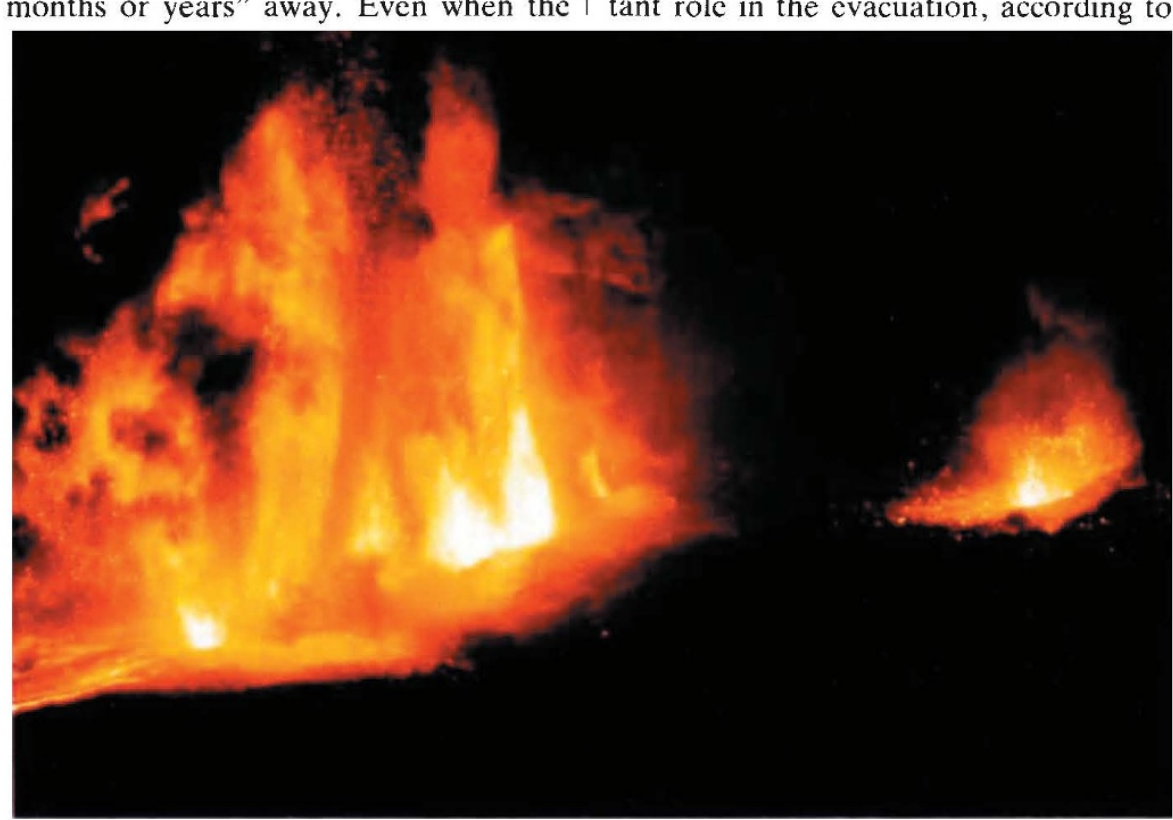

The Mount Mihara eruption at its peak on the night of 21 November.

lava started spewing out of the volcano। Professor Aramaki of Tokyo University two weeks later, it was confidently predicted that the flows would be confined to the caldera. But when a new line of vents broke through the caldera rim, sending lava surging towards the main town Motomachi, and the island had to be evacuated. the council turned about and started issuing warnings that mixing of sea water and magma could lead to a phreatomagmatic eruption, as at Krakatoa.

Now, almost a month later, with the volcano silent and the government running up huge bills to support the evacuees, the council has been under pressure to issue an all-clear. Finally, last Friday, its members adopted a "unified view" that Mount Mihara is now calm "in the short term"; the Tokyo Metropolitan Government immediately announced that the islanders would be allowed to return to Oshima between 18 and 22 December. But the council's decision was given on the precondition that the island's volcanomonitoring network be substantially up- graded before the islanders return.

The number of seismometers on the island will be almost doubled, to nineteen. Seventeen new tiltmeters will be put in place along with various other pieces of equipment costing a total of $\mathrm{Y} 1,100 \mathrm{mil}$ lion ( $£ 5$ million). The seismometers will be linked to telephone lines and $40 \mathrm{en}$ gineers of Nippon Telephone and Telegraph are racing to link the seismometers to a telemetric network by 19 December.

Preliminary analysis of the November data suggests that prediction will still be unreliable, and that details will often be discovered only after the event. Seismograph data did, however, play an important role in the evacuation, according to Earthquake Research Institute, who spent the night of 21 November at a police station in Motomachi. A shift in the earthquake swarms to a position off the southeast coast of Oshima, reported by telephone to Aramaki by researchers at Tokyo University's observatory on the island, coincided with police reports of new cracks in a road near Habu, the south-east port of Oshima; acting under Aramaki's advice, police removed evacuces from Habu to the northern ports of the island.

The new equipment will be operated by Tokyo University and the Meteorological Agency as well as various other government agencies. But it remains to be seen whether they can work together. While Tokyo University researchers stuck to their posts on 21 November, as a river of lava bore down on their observatory, officials of the nearby Metcorological Agency Observatory were among the first to flee the island. Feelings between the two groups are strained. David Swinbanks 